\title{
FORMATION OF MODERN INCENTIVE SYSTEM FOR MANAGERS IN THE CONTEXT OF EUROPEAN INTEGRATION PROCESSES
}

\author{
Olesia Vashchuk' \\ National University "Odessa Law Academy", Ukraine
}

\begin{abstract}
The article is devoted to the research of issues of the formation of the modern system of evaluation of effectiveness and motivation of managers and workers of an enterprise in the context of European integration processes in Ukraine. The object is theoretical and practical foundations of creating an efficient motivational profile of an organization with the help of formation of the modern system of employee efficiency analysis and formation of an individual system of employee motivation at the enterprise based on research of incentive systems of developed countries and EU countries. The main research objectives are established: determination of key priorities for the formation of the system of valuation and motivation; formation of an algorithm and economic and mathematical model of the system of evaluation and motivation of personnel efficiency, zoning of boundary priorities and formation of a matrix of opportunities, formation of an effective system for improving the system of personnel motivation and evaluation, and a model of the system of improvement of personnel motivation means. Methodology. The conducted comparative analysis of various motivation systems existing in the EU countries and the most developed countries allowed developing a hypothesis about the necessity to form a more effective system of personnel evaluation and motivation that would correspond to general European values and criteria. A model of motivation is proposed that is developed on the basis of the Management Functional Assessment Model (MFAM), which is elaborated by researchers of Sheffield Hallam University (Great Britain) and the company "IVA Consulting Group". MFAM is based on six main management functions: Forecasting/Planning, Organization, Motivation, Control, Coordination, and Communication. Its main advantages are the evaluation by three parameters: personnel loyalty; personnel performance; company's attractiveness in the labour market, information about which is available in free and convenient access. Evaluation of the enterprise management system based on the functional model (MFAM) is carried out by questionnaire method. Questions of the express evaluation questionnaire are divided into five groups according to model criteria. By an obtained mathematical model, analytical indicators, and grading scale, we define zones of effectiveness where enterprise management is taking place and build a matrix of opportunities for development of enterprise efficiency. Result. The research conducted confirms the methodology's efficiency, its uniqueness, and instrumental suitability. Based on experimental calculations, the algorithm of formation of performance evaluation system is determined, gradients and limits of the enterprise development are identified, the matrix of opportunities is formed, directions to improve the system of personnel motivation and evaluation are formed, and the model of the system for improving personnel motivation means is developed. Results of the enterprise personnel performance evaluation according to the developed system of indicators gave a possibility for managers of the company: to make a separate generalized profile of the appropriate group of the most successful co-workers; to form profiles of ideal co-workers, which are built given the idea of the leadership about the optimal combination of motivating factors, and to form effective directions for improving the motivation system.
\end{abstract}

Key words: European integration motivation criteria, motivation system, MFAM, performance evaluation, matrix of opportunities, motivation system improvement, motivation model.

JEL Classification: $\mathrm{H} 87, \mathrm{H} 89$

\section{Introduction}

Prospects of Ukraine's integration into European space provide for the activation of the use of a set of tools, mechanisms, factors aimed at the formation of a socially oriented value system and the promotion of personnel, the creation of a modern system of personnel motivation.

At the same time, while focusing on pan-European values, it should be noted that the level and quality

Corresponding author:

${ }^{1}$ Department of Criminalistics, National University "Odessa Law Academy".

E-mail:vaschuk@onua.edu.ua 
of human resources are an important foundation for development. In particular, the main tasks of the EU regional policy are: creating conditions for the development of viable entrepreneurship; support for economic restructuring; mastering of new production and management technologies; guaranteeing the provision of essential services to the population (training, educational, communal, medical aid); support for a new network and infrastructure; stimulating the development of tourism; restoration of the potential of territories of the country and separate regions.

The most striking differences in the level of economic well-being between Ukraine and the EU countries are observed in the process of comparing the well-being of citizens because the inherent confidence of citizens of the EU countries in the effective functioning of formal institutions and their awareness of a significant number of risks associated with the use of informal institutions are a factor of the openness of economic life and development.

In Ukraine, such institutions include: financial intermediaries and speculators who provide loans at excessive rates; personnel agencies, which reduce labour costs and employ for illegal work abroad; employers who pay low salaries or generally avoid payments. All of the above factors cause limited access to the necessary economic resources, low wages, reduced employment, poor quality of medical and cultural services, and are accompanied by a decrease in the quality of manpower, gaining profit in a dishonest way, the absence of moral order, corruption, bribery.

Such a situation contributes to the emergence of barriers to the adaptation to EU standards, which can be overcome by stimulating competition, developing the social and market infrastructure of the country, and improving the quality of its human resources.

Thus, Ukraine's integration into European space envisages activating the use of a set of tools, mechanisms, factors that are aimed at forming a socially oriented system of motivation and development of management that is an actual direction of research both for Ukraine and for other countries.

The purpose is to create a system for assessing the performance and a system of the motivation of managers and employees of the enterprise, which would meet modern standards and requirements in the context of Ukraine's European integration.

The main research objectives are: the definition of key priorities for the formation of a system of assessment and motivation; the formation of the algorithm and the economic and mathematical model of the system for assessing and motivating the efficiency of personnel, zoning of the boundary priorities and forming a matrix of opportunities, the formation of an effective system for improving the system of personnel motivation and evaluation and the model of the system for improving personnel motivation means.

\section{Presentation of the main material}

In the presence of limited financial resources, enterprises of various sectors of the economy of Ukraine are looking for ways to enhance the competitiveness of their enterprises by increasing the personnel motivation to work and creating an adequate system of personnel management that can influence the behaviour of personnel, directing it to a more productive work, achieving competitive results of work and goals of the enterprise in the conditions of dynamic changes of the environment (Iliash, Kaperyz, 2011).

Each company has its own individual profile of motivational factors that need to be managed (Larka, Zorina, 2016).

There are a number of requirements that should be guided by the creation of a system of stimulation (Day, Wensley, 1988; Hutorova, 2009; Kozak, 2011):

1) objectivity: the size of the employee's remuneration should be determined on the basis of an objective assessment of the results of his work;

2) predictability: an employee must know what remuneration he will receive depending on the results of his work;

3) adequacy: the remuneration should be adequate to the labour contribution of each employee as a result of activities of the whole team, his experience and level of qualification;

4) timeliness: the reward should follow the achievement of the result as soon as possible (if not in the form of

Table 1

Comparison of motivation systems in different countries

\begin{tabular}{|c|l|l|}
\hline Country & \multicolumn{1}{|c|}{ Key signs of labour motivation } & \multicolumn{1}{c|}{ Characteristic features of the formation of motivation system } \\
\hline USA & $\begin{array}{l}\text { Stimulation of entrepreneurial } \\
\text { activity. Quality of execution. High } \\
\text { qualification. }\end{array}$ & $\begin{array}{l}\text { Participation in the company's profits and development. A combination } \\
\text { of hourly and subcontract payment systems. Premiums for trouble-free } \\
\text { work, long-term operation of equipment. Compliance with technological } \\
\text { discipline. Dual-track system. }\end{array}$ \\
\hline Great Britain & $\begin{array}{l}\text { Income. Participation in profits in the form of } \\
\text { a distribution of shares positively affects both } \\
\text { the company and its employees, improves } \\
\text { their attitude to work, creates a favourable } \\
\text { atmosphere in the company, and stimulates } \\
\text { more efficient work. }\end{array}$ & $\begin{array}{l}\text { There are two profit-dependent types of modification of labour } \\
\text { remuneration: cash and equity, which involves partial payment in } \\
\text { shares. Work share participation. The employee receives income in three } \\
\text { directions: basic salary, the share of income participation on the basis of } \\
\text { labour, the share of profit based on the capital invested. }\end{array}$ \\
\hline
\end{tabular}


End of Table 1

\begin{tabular}{|c|c|c|}
\hline France & $\begin{array}{l}\text { Level of qualification. Quality of work. A } \\
\text { number of rational suggestions. Level of } \\
\text { mobilization. }\end{array}$ & $\begin{array}{l}\text { Three approaches to individualization of wages: - in each workplace, the } \\
\text { minimum wage and salary "brackets" are determined. The assessment } \\
\text { of the work of each employee is carried out in relation to the work } \\
\text { performed, - the salary is divided into two parts: set and variable, } \\
\text { reflecting the efficiency of labour. Additionally paid awards for high- } \\
\text { quality work; - enterprises are engaged in profits, sales to employees of the } \\
\text { enterprise shares, payment of premiums. Score evaluation of professional } \\
\text { skills, quality and productivity, compliance with safety, business ethics, } \\
\text { participation in public life, initiative. }\end{array}$ \\
\hline Germany & $\begin{array}{l}\text { Quality of work. A person with his/her } \\
\text { interests as a free personality, aware of his/ } \\
\text { her responsibility to society. }\end{array}$ & $\begin{array}{l}\text { A harmonious combination of labour stimulation and social guarantees is } \\
\text { one of the best models ever known in the history of economic theories. }\end{array}$ \\
\hline Sweden & $\begin{array}{l}\text { Joint liability and wages based on the } \\
\text { following principles: equal pay for equal } \\
\text { work, reduction of the gap between the size } \\
\text { of the minimum and maximum wages. }\end{array}$ & $\begin{array}{l}\text { The very system of determining the uniform level of wage increases } \\
\text { contributes to its alignment: earnings rise for low-paid and restrained for } \\
\text { highly-paid employees. The differentiated system of taxes and benefits. } \\
\text { Collective social policy. }\end{array}$ \\
\hline Japan & $\begin{array}{l}\text { Labour effectiveness. Professional skills. } \\
\text { Definition of age and length of service. }\end{array}$ & $\begin{array}{l}\text { Flexible incentive system. Salary is established according to the tariff } \\
\text { scheme, which determines the conditionally constant part of the salary of } \\
\text { the employee as the amount of payments in three sections: for age, for the } \\
\text { length of work, for qualification and skills, characterized by category and } \\
\text { grade. Synthesized systems, where wages are determined by four indicators } \\
\text { - age, length of employment, professional level, and labour productivity. } \\
\text { Lifetime employment of a worker. }\end{array}$ \\
\hline Ukraine & Labour productivity and efficiency. & $\begin{array}{l}\text { The economic connection of goals of the personnel and the enterprise (to } \\
\text { achieve the goals, the award is set). The predominant use of non-material } \\
\text { and socio-psychological methods of motivation. }\end{array}$ \\
\hline
\end{tabular}

(Compiled by the author based on: Kushneryk, 2012)

direct remuneration, then at least in the form of a record for the next reward);

5) significance: the remuneration must be significant for the employee;

6) fairness: rules for determining the remuneration should be clear to each employee of the organization and be fair, including from the employee's point of view.

Comparative analysis of personnel motivation mechanisms at Ukrainian enterprises and enterprises of the developed market economy showed that domestic enterprises in the choice of motivation methods are oriented mainly on the work performance while ignoring the quality of work, professional skills and qualifications of the worker. Participation in capital and profit as one of the most effective motivational methods is almost not used in other countries.

\section{Methodology}

When developing a system of motivation, one must strictly adhere to the following basic principles: to pay for the result or for success; use only the transparent rules governing the difference in incomes between different groups and categories of employees; manage expectations of employees, if the motivation system created does not justify expectations of employees, it will not work; compete in the labour market.

We propose to form a modern model of motivational evaluation based on the evaluation management model
MFAM, which is elaborated by researchers of Sheffield Hallam University (Great Britain) and the company "IVA Consulting Group” (Watson, Maslow, Chileshe, 2004).

MFAM is based on six main management functions: Forecasting/Planning, Organization, Motivation, Control, Coordination, and Communication.

First five functions of management correspond to five evaluation criteria of the model and form a management structure that, in turn, determines the nature of relationships of the organization, that is, its communication.

The efficiency of the proposed motivation system should be evaluated according to three parameters:

1. Personnel loyalty.

2. Personnel performance.

3. Company's attractiveness in the labour market.

Personnel loyalty is estimated within a month after the introduction of new motivational schemes based on the coefficient of fluidity. For example, after the announcement of a new system of motivation in a large retail network, where staff turnover was more than $50 \%$, this figure dropped to zero for several weeks. To estimate performance, more time is required, depending on the motivation system's goals. If employees need to focus on the growth of company value, it will take several years to see the results, and if on the increase in sales - a quarter or six months. Attractiveness in the labour market is assessed on the basis of indicators such as the number of candidates for a vacancy or the percentage of those 
employees who agreed with the number of those whom the company made the offer.

It should be noted that redesigning and adjusting the system of motivation is a process, if not continuous, that is, at least cyclic.

Companies are constantly evolving, their market environment is changing, and new tasks are put before business in general and before separate units. Over time, existing incentive mechanisms inevitably reduce relevance and effectiveness. Therefore, it is very important to periodically monitor the performance of the incentive system and its compliance with the business goals and objectives. Then the process of the redesign will be planned rather than an emergency (Watson, Chileshe, Maslow, 2004).

Assessment of the management system of the organization based on the functional model (MFAM) is carried out by the method of questioning. The questions of the express assessment questionnaire are divided into five groups according to the criteria of the model (see Table 2).
Each question has five answers. Recall the scale of assessment (Table 3). The highest score for each of 25 rating categories (questions) is 4 points. Accordingly, the maximum result for each of these five criteria is 20 points.

Table 3

The scale of management activity evaluation

\begin{tabular}{|c|l|}
\hline $\begin{array}{c}\text { Scale of } \\
\text { evaluation }\end{array}$ & \multicolumn{1}{c|}{ Category status } \\
\hline 0 & Activities are not conducted \\
\hline 1 & Activities are changing from time to time \\
\hline 2 & Activities are partly, depending on the situation \\
\hline 3 & $\begin{array}{l}\text { Activities are conducted on a regular and systematic } \\
\text { basis }\end{array}$ \\
\hline 4 & $\begin{array}{l}\text { Activities are conducted as efficiently as possible } \\
\text { (reference level) }\end{array}$ \\
\hline
\end{tabular}

Compiled by the author

It should be noted that this evaluation is carried out not only by managers, specialists of different levels but

Table 2

Method of two-way express evaluation by the criteria of MFAM

\begin{tabular}{|c|c|c|}
\hline Criterion/Category & Maximum & Estimation \\
\hline 1. Planning & $(20)$ & \\
\hline 1.1. Setting goals and strategic objectives & 4 & \\
\hline 1.2. Collecting and analysing customer and market information & 4 & \\
\hline 1.3. Detailing the business process & 4 & \\
\hline 1.4. Collecting and analysing information about competitors and benchmark companies & 4 & \\
\hline 1.5. Resource planning & 4 & \\
\hline 2. Organization & $(20)$ & \\
\hline 2.1. Formation of organizational structure & 4 & \\
\hline 2.2. Distribution of powers and establishment of areas of responsibility & 4 & \\
\hline 2.3. Conditions for self-education & 4 & \\
\hline 2.4. Implementation of the main process & 4 & \\
\hline 2.5. The effectiveness of the process of creating new values for customers & 4 & \\
\hline 3. Motivation & $(20)$ & \\
\hline 3.1. Leadership and corporate culture & 4 & \\
\hline 3.2. Conditions for training and professional development of personnel & 4 & \\
\hline 3.3. The level of employees' needs & 4 & \\
\hline 3.4. Involvement of employees in the process of improvement & 4 & \\
\hline 3.5. Satisfaction of employees with the results of their activities & 4 & \\
\hline 4. Control & $(20)$ & \\
\hline 4.1. Quality control system at every stage of the business process & 4 & \\
\hline 4.2. Criteria for evaluating the results & 4 & \\
\hline 4.3. Measuring the degree of consumer satisfaction & 4 & \\
\hline 4.4. Rational use of resources & 4 & \\
\hline 4.5. Correspondence of the obtained results to the established goals & 4 & \\
\hline 5. Coordination & $(20)$ & \\
\hline 5.1. Connection and coordination of the first four functions & 4 & \\
\hline 5.2. Establishing internal interrelations of the organization & 4 & \\
\hline 5.3. Conflict resolution system & 4 & \\
\hline 5.4. Current deviation analysis: view and adjust plans & 4 & \\
\hline 5.5. Information management & 4 & \\
\hline 6. Communication (general management assessment $=\sum$ criteria 1-5) & $(100)$ & \\
\hline
\end{tabular}

Compiled by the author based on: Watson P., Chileshe N., Maslow D. A., 2004 
also by ordinary employees, that is, those who make managerial decisions. For obtaining objective data, the necessary condition is the survey participation of not less than $80 \%$ of managers and not less than $50 \%$ of employees. The average score for each of 25 rating categories (questions) is calculated according to the formula (maximum 4 points):

$$
I_{c p . n}=\frac{I_{p y x . n}+I_{p a \sigma . n}}{2}
$$

where:

$\mathrm{I}_{\text {cp.n }}$ - average score by the category;

$\mathrm{I}_{\text {pyк.n }}$ - average evaluation of leaders;

$\mathrm{I}_{\text {paб.n }}$ - average evaluation of employees;

$\mathrm{n}$ - evaluation category (question).

An estimate of each criterion is the sum of average scores of the categories corresponding to this criterion (maximum 20 points):

$$
I_{\text {кpum. }}=\sum_{n=1}^{5_{\text {cp.n }}}
$$

where

$\mathrm{I}_{\text {крит. }}$ - general estimation by criterion;

$\mathrm{I}_{\mathrm{cp.n}}$ - average score by the category;

$\mathrm{n}$ - evaluation category.

Total Management Estimation (TME) of the organization is determined by the sum of estimations for all five evaluation criteria of MFAM (maximum 100 points):

$$
T M E=\sum \sum_{n=1}^{5} I_{\kappa p u m}
$$

where:

TME - Total Management Estimation;

$\mathrm{I}_{\text {крит. }}$ - the estimate for each criterion; $\mathrm{n}$ - estimation criterion.

Adequacy of the management of the enterprise is determined as follows: the advantage of the bilateral assessment system is that it can be determined how the leaders' presentation of the situation in the company is consistent with the opinion of employees. Evaluation of leaders $\left(\mathrm{I}_{\mathrm{pyk}}\right)$ for each of 25 rated categories is compared with the corresponding evaluation of workers $\left(\mathrm{I}_{\mathrm{pa}}\right)$. The coefficient of management adequacy (KAM) is calculated using the following formula:

$$
K_{A M}=\frac{I_{p y \kappa}-I_{p a \sigma}}{4}
$$

where: KAM - coefficient of management adequacy;

$\mathrm{I}_{\mathrm{py \kappa}}$ - average evaluation of managers;

$\mathrm{I}_{\text {pa }}$ - average evaluation of employees;

4 - the maximum possible score by the category.

An analysis of the coefficient of management adequacy by individual evaluation categories can be conducted using the graph (see Figure 1).

Adequate estimation zone of management capabilities: from $-0,1$ to 0,1 (upper and lower points are included in this zone).

Indicators of this zone characterize the adequate perception of employees of management decisions, the leader and the team are guided by the same principles in the work, which contributes to the harmonious development of the organization. Managers, using such a situation, have an opportunity to continuously improve the business process.

Underestimation zone of management capabilities: from -1 to $-0,1$ (the lower point is included in this zone).

The underestimation zone indicators reflect the lack of leadership skills of enterprise managers. There are potential opportunities to improve the management system. Employees evaluate the activities of the company higher than leaders. It is needed to use this situation to adjust the position of managerial personnel and to enhance the processes of improvement.

Overestimation zone of management capabilities: from 0,1 to 1 (the top point is included in this zone).

Indicators of the overestimation zone reflect differences in the opinions of leaders and employees regarding the situation in the enterprise. In this case, most managerial

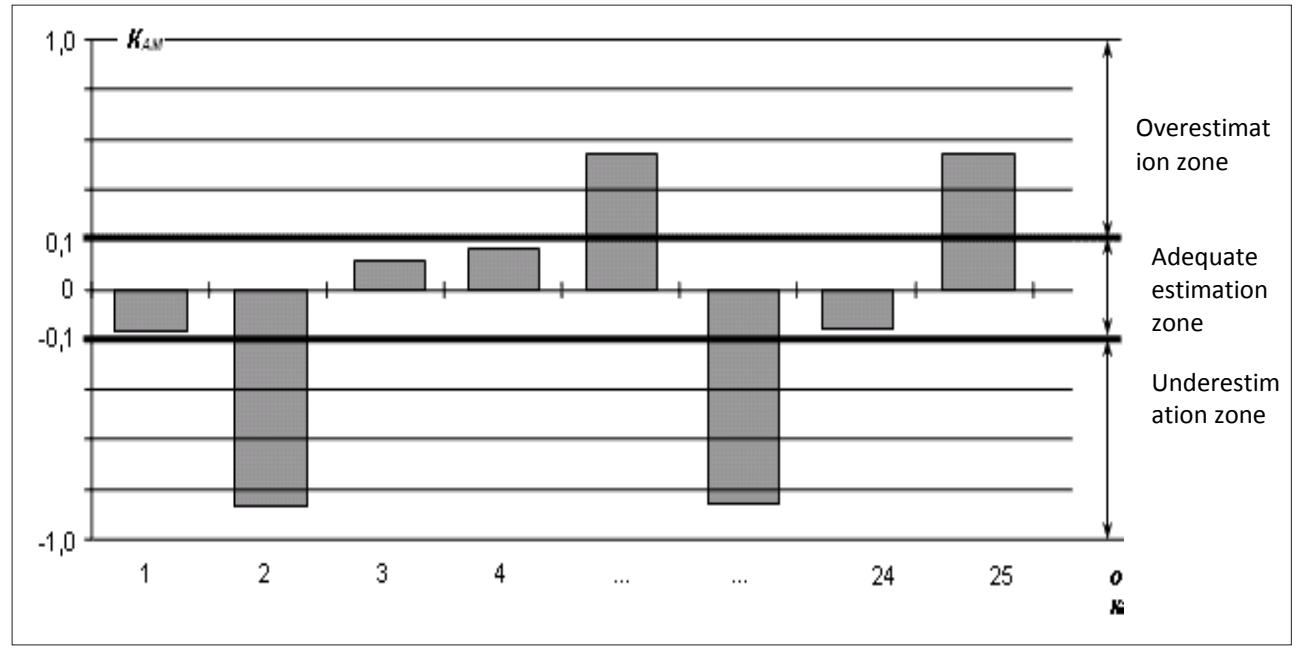

Fig. 1. Zonal distribution of estimation criteria 
decisions may face the internal resistance of the team, and various kinds of transformations initiated by management will be completely ineffective (Korytko, 2012).

The primary tasks of management here are: the identification of causes of inconsistencies, analysis of categories, where the maximum differences in the evaluation are traced; establishing a more close contact with personnel; determining the degree of employee satisfaction; strengthening corporate culture.

\section{Personnel cohesion.}

An important element of the analysis in the system of self-assessment on the basis of MFAM is the definition of the personnel cohesion coefficient (KCK). This ratio reflects the polarity of opinions within the organization. For each question (category), the variance of employee estimates is calculated according to the following formula 5:

$$
K_{C K}=\frac{m \sum\left(I_{\text {раб. } n}\right)^{2}-\left(\sum I_{\text {раб. } n}\right)^{2}}{m^{2}}
$$

where

KCK - personnel cohesion coefficient;

$\mathrm{m}$ - the number of interviewed employees;

$\mathrm{I}_{\text {paб. }}$ - evaluation of employee;

$\mathrm{n}$ - the number of the question (category).

An analysis of responses of employees makes it possible to identify the zone of unity and polarity of opinions in the staff. The zone of unity is within the value of the coefficient of agreement from 0 to 1 inclusive.
In the zone of polarity, the value of the coefficient, respectively, is between 1 and 4. The categories, by which workers gave an equivalent assessment, have a greater potential for making effective changes, as the situation in this area is equally perceived by the entire personnel. Indicators in the polarity zone require a top-priority analysis of reasons for the discrepancies. Otherwise, any improvement plans will be inadequately perceived by the personnel, and the effectiveness of the changes will be at best low, or the effect will be negative at all (Kindermann, 2002; Dykan, 2008).

Further analysis of the survey results involves identifying correlations between the coefficients of management adequacy and the personnel cohesion coefficient. The main task of the final stage of selfevaluation is to more accurately determine the effectiveness of changes in one area or another. The analysis tool here is the matrix of opportunities for improvement (see Fig. 2).

Depending on which of the zones a point with coordinates (KCK; KAM) falls, the degree of improvement opportunities on the investigated indicator is determined. We distinguish four zones of analysis:

1. Effective zone: the effectiveness of the program for improving management efficiency is high.

2. Working zone: the stable probability of improvement.

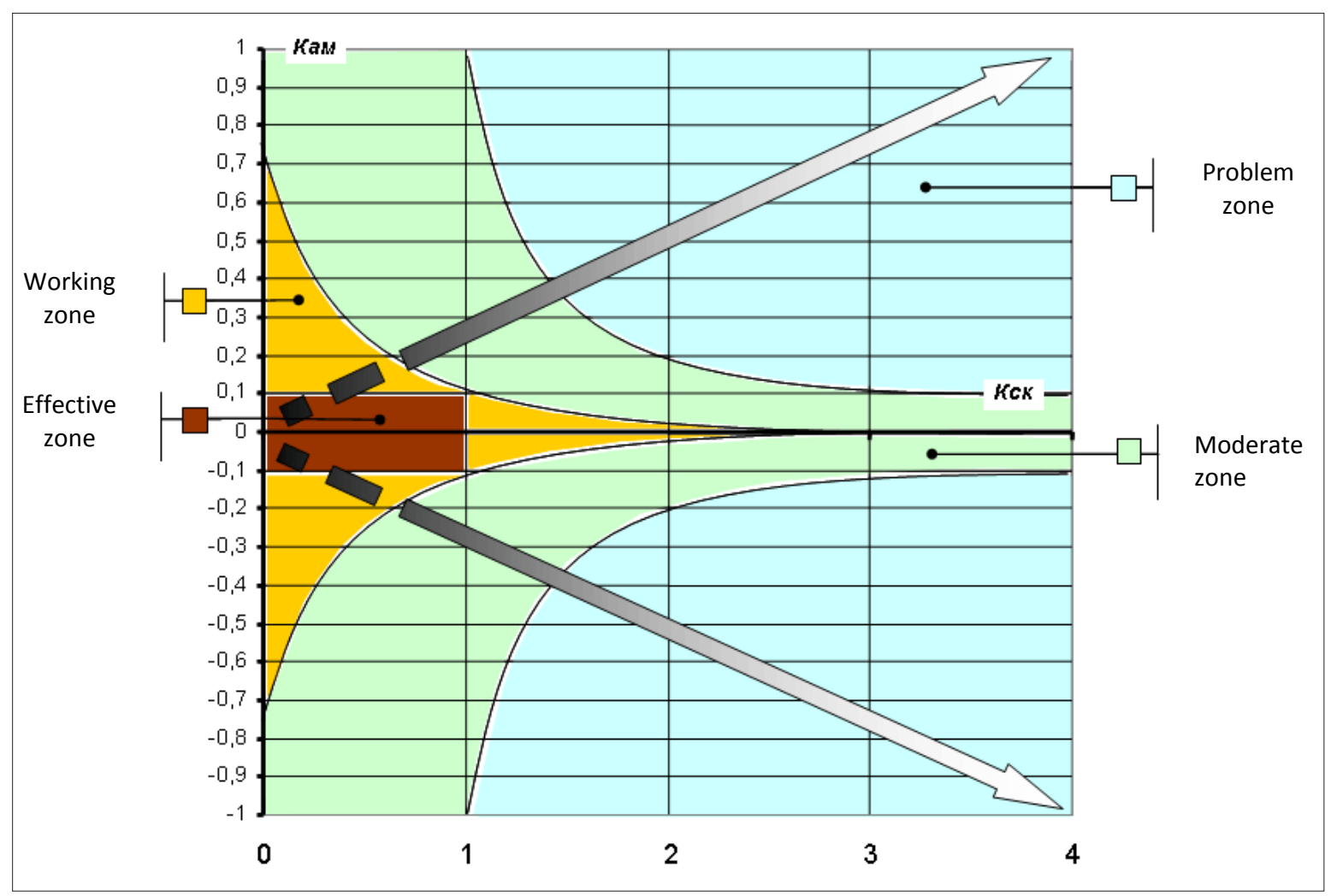

Fig. 2. The matrix of opportunities for developing efficiency 
3. Moderate zone: implementation of a program of improvement requires a detailed preparation and preliminary analysis of coefficients.

4. Problem zone: the development and implementation of a program of improvement should begin after a thorough examination of the unsatisfactory indicators of KCK, KAM.

\section{Result}

The experience of the experimental application of the model shows that the functional evaluation model helps to systematize the management approach, thus enhancing competitiveness and improving business results of organizations. In Table 4, we specified the competitive advantages that the enterprise received by using the MFAM.

In general, the algorithm of organizational self-esteem based on a functional model of management assessment can be represented as follows:

Step 1: Calculating the overall management assessment.

Step 2: Analysis of the results obtained for 25 categories of the model.

Identification of strong and weak areas in the management system.

Step 3: Calculation of the coefficient of management adequacy, KAM.

Step 4: Calculation of the personnel cohesion coefficient, Кск.

Step 5: Building a matrix of opportunities for improvement.

Analysis and definition of possible directions for improvement.
Table 4

Competitive advantages when applying

a functional model of self-esteem

\begin{tabular}{|l|l|}
\hline \multicolumn{1}{|c|}{ Key growth points } & \multicolumn{1}{c|}{ Competitive advantages obtained } \\
\hline Improvement of processes & $\begin{array}{l}\text { A clear understanding of how to } \\
\text { create value for the consumer }\end{array}$ \\
\hline $\begin{array}{l}\text { Achievement of the } \\
\text { organization's goals }\end{array}$ & $\begin{array}{l}\text { Implementation of strategic goals } \\
\text { and objectives, based on available } \\
\text { opportunities and disclosure of the } \\
\text { organization's strengths, taking into } \\
\text { account the views of employees }\end{array}$ \\
\hline $\begin{array}{l}\text { Comparison of key } \\
\text { performance results with } \\
\text { benchmarking }\end{array}$ & $\begin{array}{l}\text { Ability to measure the dynamics } \\
\text { of improvement and the level of } \\
\text { achievement of the set goals, having } \\
\text { determined the limits }\end{array}$ \\
\hline $\begin{array}{l}\text { Development of an } \\
\text { operational planning } \\
\text { system based on the } \\
\text { organization's policy and } \\
\text { strategy }\end{array}$ & $\begin{array}{l}\text { Clarity and unity of goals within the } \\
\text { whole organization contribute to } \\
\text { the effectiveness of the process of } \\
\text { continuous improvement }\end{array}$ \\
\hline $\begin{array}{l}\text { Combining all initiatives } \\
\text { to improve into a single } \\
\text { system }\end{array}$ & $\begin{array}{l}\text { Interconnection of all areas of } \\
\text { activity within the framework of } \\
\text { a systematic approach to making } \\
\text { managerial decisions }\end{array}$ \\
\hline $\begin{array}{l}\text { Development of team } \\
\text { activity }\end{array}$ & $\begin{array}{l}\text { Teambuilding on the basis of } \\
\text { common values, trust, corporate } \\
\text { culture, ethics }\end{array}$ \\
\hline
\end{tabular}

Step 6: Re-evaluation and analysis of changes (repeat steps 1-5).

In this regard, it makes sense to propose a flexible system of indicators for assessing the employee's business qualities (BQ) and evaluating the summarized results (SR) of his/her work, the essence and content of the indicators and their score are disclosed in Table 5.

Table 5

Essential distribution of indicators of labour evaluation by criteria

\begin{tabular}{|c|c|c|c|c|}
\hline \multirow{2}{*}{$\begin{array}{l}\text { The essence of the } \\
\text { indicator and its } \\
\text { evaluation }\end{array}$} & 1-low & 2-middle & 3-high & 4-highest \\
\hline & $\begin{array}{l}\text { Extremely unsatisfactory } \\
\text { results }\end{array}$ & $\begin{array}{c}\text { Rather unsatisfactory than } \\
\text { satisfactory }\end{array}$ & $\begin{array}{l}\text { Quite satisfactory, but not } \\
\text { always excellent results }\end{array}$ & Always excellent results \\
\hline \multicolumn{5}{|c|}{ Signs (criteria) of the employee's business qualities (BQ) } \\
\hline \multirow[t]{2}{*}{$\begin{array}{l}\text { 1. Diligence within the } \\
\text { scope of labour duties. } \\
\text { Readiness to perform } \\
\text { production tasks } \\
\text { entrusted by the manager. }\end{array}$} & $\begin{array}{l}\text { Undiligent, inclined to } \\
\text { avoid receiving new tasks } \\
\text { under any circumstances. }\end{array}$ & $\begin{array}{l}\text { Low level of diligence. } \\
\text { Sometimes tries to avoid } \\
\text { getting new tasks. }\end{array}$ & $\begin{array}{l}\text { A good level of diligence, } \\
\text { but not every day without } \\
\text { exception. }\end{array}$ & $\begin{array}{l}\text { Excellent level of } \\
\text { diligence. Always perform } \\
\text { duties and assignments. }\end{array}$ \\
\hline & 0,20 & 0,30 & 0,50 & 0,80 \\
\hline \multirow[t]{2}{*}{$\begin{array}{l}\text { 2. Ability to cope with } \\
\text { duties and instructions. } \\
\text { Ability to identify and } \\
\text { solve emerging problems. }\end{array}$} & $\begin{array}{l}\text { Often cannot cope with } \\
\text { duties and instructions. } \\
\text { Cannot detect problems } \\
\text { and hardly solves them. }\end{array}$ & $\begin{array}{l}\text { As a rule, copes with his/ } \\
\text { her responsibilities, but } \\
\text { not always performs them } \\
\text { properly. Poorly solves } \\
\text { problems. }\end{array}$ & $\begin{array}{l}\text { Copes well with } \\
\text { responsibilities, skilfully } \\
\text { solves problems but } \\
\text { requires control from the } \\
\text { head. }\end{array}$ & $\begin{array}{l}\text { Able to handle duties } \\
\text { perfectly. Always skilfully } \\
\text { detects and quickly solves } \\
\text { problems. }\end{array}$ \\
\hline & 0,20 & 0,50 & 0,50 & 0,80 \\
\hline \multirow[t]{2}{*}{$\begin{array}{l}\text { 3. Working capacity and/ } \\
\text { or ability during each } \\
\text { working day to focus only } \\
\text { on the performance of } \\
\text { work. }\end{array}$} & $\begin{array}{l}\text { Inattentive. Able to } \\
\text { maintain efficiency for } \\
\text { a short time, constantly } \\
\text { diverting to issues not } \\
\text { related to work. }\end{array}$ & $\begin{array}{l}\text { Tired of increasing labour } \\
\text { intensity, keeps the } \\
\text { average working capacity } \\
\text { during the working day. } \\
\text { Often distracted. }\end{array}$ & $\begin{array}{l}\text { Able to maintain a fairly } \\
\text { high level of productivity } \\
\text { during the working hours, } \\
\text { but not always active. }\end{array}$ & $\begin{array}{l}\text { Active throughout the } \\
\text { working day. Always } \\
\text { ready to work hard and } \\
\text { intensely. All attention is } \\
\text { concentrated only on work. }\end{array}$ \\
\hline & 0,20 & 0,30 & 0,50 & 0,80 \\
\hline
\end{tabular}


End of Table 5

\begin{tabular}{|c|c|c|c|c|}
\hline \multirow[t]{2}{*}{$\begin{array}{l}\text { 4. Competence. } \\
\text { Knowledge of using } \\
\text { techniques and methods } \\
\text { of work and the ability } \\
\text { to accurately follow } \\
\text { them, the presence of the } \\
\text { necessary skills. }\end{array}$} & $\begin{array}{l}\text { Incompetent. Does } \\
\text { not possess the basic } \\
\text { techniques and methods } \\
\text { of work and does not seek } \\
\text { to master them. }\end{array}$ & $\begin{array}{l}\text { Knows the basic } \\
\text { techniques of work } \\
\text { not well, while having } \\
\text { weak skills and slowly } \\
\text { developing them. }\end{array}$ & $\begin{array}{l}\text { Knows the methods } \\
\text { of work well, but there } \\
\text { is a need for further } \\
\text { competence development. }\end{array}$ & $\begin{array}{l}\text { Competent. Excellent } \\
\text { knowledge of all methods } \\
\text { of work; strictly follows } \\
\text { them every day. }\end{array}$ \\
\hline & 0,20 & 0,30 & 0,50 & 0,80 \\
\hline \multirow[t]{2}{*}{$\begin{array}{l}\text { 5. Interests and activities } \\
\text { in matters of improving } \\
\text { the quality, productivity } \\
\text { of work, and development } \\
\text { of effective working } \\
\text { methods. }\end{array}$} & $\begin{array}{l}\text { Often opposes the } \\
\text { introduction of new } \\
\text { technologies, methods of } \\
\text { work aimed at improving } \\
\text { quality and productivity. }\end{array}$ & $\begin{array}{l}\text { Does not resist, but does } \\
\text { not show interest in issues } \\
\text { of improving the quality } \\
\text { and productivity of work. }\end{array}$ & $\begin{array}{l}\text { Always supports all } \\
\text { innovations, helps to learn } \\
\text { new methods of work. }\end{array}$ & $\begin{array}{l}\text { Not only actively helps to } \\
\text { master new methods of } \\
\text { work, but often presents } \\
\text { various innovative } \\
\text { proposals. }\end{array}$ \\
\hline & 0,10 & 0,15 & 0,25 & 0,40 \\
\hline \multirow[t]{2}{*}{$\begin{array}{l}\text { 6. Ability to maintain } \\
\text { working relationships } \\
\text { with other employees } \\
\text { of the enterprise. The } \\
\text { absence of conflict. }\end{array}$} & $\begin{array}{l}\text { Hard to get along with. } \\
\text { Often creates conflict } \\
\text { situations and tension in } \\
\text { the team. }\end{array}$ & $\begin{array}{l}\text { Not always and not with } \\
\text { everyone can maintain } \\
\text { normal working relations. }\end{array}$ & $\begin{array}{l}\text { Able to maintain working } \\
\text { relationships with } \\
\text { colleagues in work, but } \\
\text { one cannot say that he/ } \\
\text { she actively cooperates } \\
\text { with them. }\end{array}$ & $\begin{array}{l}\text { Able not only always } \\
\text { and with all to maintain } \\
\text { normal working } \\
\text { relationships, but also } \\
\text { actively cooperates with } \\
\text { others, provides them } \\
\text { with assistance. }\end{array}$ \\
\hline & 0,10 & 0,15 & 0,25 & 0,40 \\
\hline \multicolumn{5}{|c|}{ Signs (criteria) of summarized results of work of an employee (SR) } \\
\hline \multirow[t]{2}{*}{$\begin{array}{l}\text { 7. Execution of the } \\
\text { planned volume of work } \\
\text { according to assigned } \\
\text { production tasks. }\end{array}$} & $\begin{array}{l}\text { No scheduled work was } \\
\text { performed on assignments } \\
\text { in time. }\end{array}$ & $\begin{array}{l}\text { There have been cases of } \\
\text { incompleteness in the full } \\
\text { scope of the planned work } \\
\text { on assignments. }\end{array}$ & \begin{tabular}{|l|} 
Executed the entire \\
volume of the planned \\
work, but there were cases \\
of violation of terms.
\end{tabular} & $\begin{array}{l}\text { All planned work on } \\
\text { assignments was carried } \\
\text { out in full volume and in } \\
\text { due time. }\end{array}$ \\
\hline & 0,30 & 0,45 & 0,75 & 1,20 \\
\hline \multirow[t]{2}{*}{$\begin{array}{l}\text { 8. Quality of work, tasks } \\
\text { performed. }\end{array}$} & $\begin{array}{l}\text { The work was carried out } \\
\text { poorly. There were cases } \\
\text { of shortage and return of } \\
\text { tasks for work. }\end{array}$ & $\begin{array}{l}\text { Although very rare cases } \\
\text { of lack of work, there were } \\
\text { errors and shortcomings. }\end{array}$ & $\begin{array}{l}\text { The work was carried out } \\
\text { quite qualitatively, but } \\
\text { there were small errors. }\end{array}$ & $\begin{array}{l}\text { Works were executed } \\
\text { impeccably, neatly, } \\
\text { without defects, in } \\
\text { strict conformity with } \\
\text { standards. }\end{array}$ \\
\hline & 0,40 & 0,60 & 1,00 & 1,60 \\
\hline \multirow[t]{2}{*}{$\begin{array}{l}\text { 9. Discipline. Compliance } \\
\text { with labour, industrial, } \\
\text { and technological } \\
\text { discipline. }\end{array}$} & $\begin{array}{l}\text { Undisciplined, indifferent, } \\
\text { unpunctuality, there } \\
\text { was a gross violation of } \\
\text { discipline. }\end{array}$ & $\begin{array}{l}\text { There were significant } \\
\text { violations of discipline. }\end{array}$ & $\begin{array}{l}\text { Disciplined, punctual } \\
\text { in general, but there } \\
\text { were minor violations of } \\
\text { discipline. }\end{array}$ & $\begin{array}{l}\text { There was no case of } \\
\text { discipline violation during } \\
\text { the attestation period. } \\
\text { Punctual in all details. }\end{array}$ \\
\hline & 0,30 & 0,45 & 0,75 & 1,20 \\
\hline
\end{tabular}

On the basis of the assessment of the employee's business qualities (BQ) and the summarized results (SR) of his work, an integrated assessment of the enterprise personnel is calculated, using the formula:

\section{Integrated Assessment $=$}

$=($ Business Qualities $)+($ Summarized Results $)$

Comprehensive evaluation of labour, as well as indicators of business qualities and criteria of summarized results of work of an employee, are compared with the average values of the relevant indicator on the whole for the enterprise in this way: if the individual value of the indicator falls within the range of $\pm 30 \%$ of the average - the employee's activity is recognized as average, at the value more than $30 \%-$ successful, otherwise - unsatisfactory.
The flexibility of the proposed system of indicators is ensured by the possibility of carrying out a comprehensive assessment of the work of the personnel of the industrial enterprise by the general characteristics (attributes) inherent in any type of labour activity.

The results of a comprehensive evaluation of work are formalized in the form of motivational profiles individual for each employee or consolidated for a unit or the whole enterprise.

The results of evaluating the company's personnel in accordance with the developed system of indicators provided an opportunity for managers (Day, Wensley, 1988; Korytko, 2012):

- to make a separate generalized profile, corresponding to a group of the most successful employees;

- to form profiles of ideal employees, which are formed 
on the basis of the idea of the leadership about the optimal combination of motivating factors (Nikitin, Rukas-Pasichnyuk, 2016).

With the help of profiles of successful and perfect employees, one can get a set of motivators and tools of motivation, which most completely meet the requirements of the enterprise. At the same time, evaluation of the results of the personnel activities allows management to identify the most prominent workers and really raise the level of their achievements, developing significant for the company qualities and skills of the employee (Iziumtseva, Myronchuk, 2012).

The methodology for assessing the enterprise personnel efficiency is an integral part of the organizational and economic model of assessment and motivation of the work of personnel. This is due to the fact that the results of the assessment of labour efficiency conducted in accordance with the developed methodology will allow improving the system of personnel motivation at the enterprise and increasing the efficiency of the enterprise personnel management by: positive action on the motivation of employees the feedback has a beneficial effect on the motivation of employees, allows them to correct their behaviour in the workplace and achieve increased productivity.

In developing programs and measures to improve the system of assessment and motivation of personnel of an industrial enterprise, it is also necessary to take into account global trends and forecasts in personnel management (Potemkin, 2011):

- the transition of motivation to the strategic level;

- increasing participation of personnel in corporate governance;

- increase in the cost of health services and, consequently, increase in the importance of voluntary health insurance as one of the motivators;

- introduction of new information technologies in personnel management;

- aging of the labour force;

- increase in the number of claims to employers.

Proceeding from world trends and taking into account domestic specifics, to ensure the effectiveness of the system of evaluation and motivation of labour of the enterprise personnel, the following provisions must be observed:

- creation of conditions for the continuous selfimprovement of participants in labour relations at the enterprise;

- use of specialized motivational programs in expanding the authority of the team in the adoption of managerial decisions;

- formation of new market values of labour, shared by all participants in production processes;

- flexible and adaptive use of human resources, the formation of a humanized organizational culture of the enterprise.
On the basis of these principles, it is possible to give grounded priority directions for improving the system of motivation and evaluation of labour of the personnel of the industrial enterprise, which are presented in Table 6 (Semenov, Sharko, 2009; Semikina, 2011).

Improvement of personnel motivation system at the industrial enterprise means reconstruction of the structure of motivating factors - the process is long and hard to foresee. Methods may vary from the creation of a system of internal corporate measures to change the corporate culture or the structure of business processes (extension of powers of certain groups of employees, change of control system). The main principle of changes: a new system of motivation should meet the enterprise goals (Semikina, 2011).

Having analysed Table 6, it can be seen that, for example, the remuneration system for superannuated work has much greater versatility than the scheme of share participation in business (Temchenko, Lisnichenko, 2010).

Basic motivation means allow satisfying mostly firstlevel needs. Additional means provide a possibility to realize the spiritual and intellectual potential of the worker. Based on developed concepts and models of improvement of motivation means, it is possible to create a complex program. The mission of this program is to create an effective system of personnel motivation that ensures an increase in the business activity of employees on the basis of the disclosure of their personal potential.

The main objectives of the program are to increase the personnel's interest in high-performance work and develop a system of compensation payments and benefits for personnel.

Today, when due to a difficult economic situation, a special attention should be paid to non-material stimulation, creating a flexible system of employee benefits, humanizing work, in particular:

- to recognize the value of an employee for the organization, to provide him with creative freedom, to apply programs of enrichment of work and rotation of staff;

- to use flexible schedule, part-time working week, opportunity to work both in the workplace and at home; - to set discounts on the products produced by the company (to issue cards for the use of gasoline);

- to provide facilities for recreation and leisure, provide free vouchers, issue loans for the purchase of housing, garden area, motor vehicles, and so on.

It is advisable to form the motivational system at the enterprise in such a way that each employee is interested in delegating him a greater share of authority and directing each work to a positive result. It is necessary to develop performance indicators for employees based on the strategic objectives of the enterprise, and not simply to make the implementation of certain indicators dependent on wage payment. In this way, each employee will work to achieve the goals set by the enterprise 
Table 6

\section{The formed directions for improving the system of motivation and evaluation of personnel work}

\begin{tabular}{|c|c|}
\hline Directions for improving & The essence and possible results of the implementation \\
\hline $\begin{array}{l}\text { The motivation of the personnel by its } \\
\text { external hobbies. }\end{array}$ & $\begin{array}{l}\text { The passion for external interests - sports, hobbies, or other things that are not directly } \\
\text { related to work, is typical for dynamic employees who have a significant growth potential. } \\
\text { Aspirations of employees to achieve high results in the area they are interested can be } \\
\text { used to stimulate their growth and motivation in the workplace. The positive attitude and } \\
\text { encouragement from the management of interests of personnel are positively reflected in his/ } \\
\text { her work. In addition, the management, possessing information about employee's external } \\
\text { hobbies, receives additional and effective tools of his/her labour motivation. }\end{array}$ \\
\hline $\begin{array}{l}\text { Independent personnel assessment of the } \\
\text { degree of success of the work performed. }\end{array}$ & $\begin{array}{l}\text { Employees, who constantly monitor their activities, are able to notice and document the } \\
\text { growth of their own professionalism. They create for themselves a table of ratings and } \\
\text { celebrate their victories and defeats better than the leader. The incentive and encouragement } \\
\text { of the personnel as a result of self-assessment by the management provides additional } \\
\text { motivational. }\end{array}$ \\
\hline $\begin{array}{l}\text { Individual approach to the motivation of } \\
\text { each employee. }\end{array}$ & $\begin{array}{l}\text { Different employees have different goals and desires and, therefore, they need to provide } \\
\text { different opportunities for work and professional growth. To increase motivation, one } \\
\text { needs to find an individual approach to each subordinate. One of the ways is to delegate the } \\
\text { authority, goals, and objectives to each employee when developing a general plan or project. } \\
\text { Another way is to provide subordinates the opportunity to independently develop their own } \\
\text { strategic tasks and plans. }\end{array}$ \\
\hline $\begin{array}{l}\text { Operative data exchange within the } \\
\text { enterprise on the work of personnel. }\end{array}$ & $\begin{array}{l}\text { Allows timely receiving and monitoring the performance of employees and fulfilling their } \\
\text { official duties, production tasks, and orders of leaders. The more information and operational } \\
\text { exchange, the higher the motivation. }\end{array}$ \\
\hline $\begin{array}{l}\text { Availability for the staff of remuneration } \\
\text { system accepted. }\end{array}$ & $\begin{array}{l}\text { Arbitrary incentives and rewards negatively affect motivation. If the program of motivation is } \\
\text { not enough for employees, it is necessary to explain in detail its essence, goals and tasks, the } \\
\text { possibility of influencing their current activities. }\end{array}$ \\
\hline Creation of a bank of ideas. & $\begin{array}{l}\text { Most of the ordinary employees have their opinion and a number of ideas about improving } \\
\text { the technology and production and economic activities of the enterprise as a whole. Thanks } \\
\text { to practical knowledge and proximity to production processes, some employee ideas are } \\
\text { valuable to management. }\end{array}$ \\
\hline Motivation by knowledge. & $\begin{array}{l}\text { In order to achieve professionalism in any work, an employee should strive to become the } \\
\text { best in his specialty. A person enthusiastic about learning will necessarily grow up in office } \\
\text { and develop additional useful skills. }\end{array}$ \\
\hline $\begin{array}{l}\text { Awarding individuals for the total } \\
\text { contribution of the group. }\end{array}$ & $\begin{array}{l}\text { In teamwork, individual merits of employees often remain unaccounted for, as companies } \\
\text { tend to recognize the success of the group as a whole. However, direct heads and colleagues } \\
\text { need to note the contribution of individual employees to the general business, only so a } \\
\text { person can be encouraged and motivated to further activities. }\end{array}$ \\
\hline $\begin{array}{l}\text { Support for the positive exchange of } \\
\text { information between employees. }\end{array}$ & $\begin{array}{l}\text { Personal positive evaluations of the work of employees are an effective motivating factor. A } \\
\text { corporate culture that supports the desire to give positive evaluations of consequences of the } \\
\text { task increases the level of motivation and productivity. }\end{array}$ \\
\hline $\begin{array}{l}\text { It is necessary to search and accept people } \\
\text { with internal motivation. }\end{array}$ & $\begin{array}{l}\text { When hiring staff, managers tend to be interested in their level of competence. However, the } \\
\text { very relation to work determines the motivation, which, in turn, has a major impact on the } \\
\text { employee's aspirations for learning and quality work. }\end{array}$ \\
\hline $\begin{array}{l}\text { Rewarding employees is expedient to carry } \\
\text { out in smaller volumes, but more often. }\end{array}$ & $\begin{array}{l}\text { Most companies have a widespread practice of awarding valuable rewards to employees and } \\
\text { paying large bonuses for the project, quarter or year. The ceremony for awarding the best } \\
\text { passes rarely and attracts a close attention of all employees of the company, but of course } \\
\text { they have less effect on motivation than not so big but more frequent incentives that give } \\
\text { employees more chance of success. }\end{array}$ \\
\hline Motivation by control & $\begin{array}{l}\text { Heads are convinced that control is their prerogative. But control can also be a motivator. The } \\
\text { main idea of this method is to provide employees with the opportunity to make decisions on } \\
\text { all issues that do not require centralized control. }\end{array}$ \\
\hline Specification and clarification of tasks. & $\begin{array}{l}\text { An employee should be clear what he is doing, why he does it, and how well he performs his } \\
\text { job. Studies have shown that the clarity of tasks more influences the motivation of employees } \\
\text { than their experience or the size of the bonus. It is possible to achieve great results if help } \\
\text { colleagues to see their personal contributions to the general business and regularly, promptly, } \\
\text { and accurately evaluate their work. }\end{array}$ \\
\hline
\end{tabular}

Compiled by the author based on: (Semikina, 2011; Temchenko, Lisnichenko, 2010 
and personally will be interested in their achievement through the system of motivation. A particular attention should be paid to the development of a motivational system for production personnel, which would reduce staff turnover and unite production personnel at the plant, creating stable groups (gangs) that would be interested in achieving the objectives set by the plant and aware of their contribution to their achievement.

To develop a system of advanced training for mid-level managers: to conduct a series of training for employees, to oblige the HR department to find specialized seminars, trainings for enterprise management, and conduct such training on an ongoing basis.

To automate the personnel department in order to facilitate and improve the work of the latter.

To improve the motivation system, one can use a motivation system that aims to improve motivation means (see Figure 3).

The basic means of motivation can satisfy mainly the needs of the first level. Additional means provide an opportunity to realize the spiritual and intellectual potential of the worker. Based on the developed concepts and models of improving the means of motivation, it is possible to create a comprehensive program. The mission of this program is to create an effective system of personnel motivation, which ensures the increase of the business activity of employees on the basis of the disclosure of their personal potential.

The main objectives of the program are to increase the interest of the staff in high-performance work and to develop the system of compensatory payments and benefits for personnel.

Thus, within the framework of the program, there are 5 main directions of activities:
- creation of a new motivational environment, which helps to identify the reserves of employees as the main resource of the organization's internal development; - development of basic organizational, regulatory, and methodological documents on the program formation; - providing methodical assistance to the heads of departments in the formation of a new motivational mechanism;

- organization of broad propagation of the program's goals and objectives;

- questionnaires and surveys of personnel to clarify the program's goals and objectives.

\section{Conclusions}

According to European choice, Ukraine launches a new process of changes that should be based on the European human-centred system of pan-European values based on the observance of the integrity of human dignity, freedom of choice and fair working conditions, the creation of equal starting conditions and opportunities for promoting development and implementation of innovative, intellectual, cultural, creative abilities of the person in the process of labour activity, access to social guarantees, satisfaction of socio-economic and psychological needs of employees, social solidarity, social mobility towards obtaining professional knowledge, mastering of innovative technologies, tolerance, etc., which is a prerequisite for the formation of an effective system of personnel motivation at domestic enterprises and is aimed at meeting the person's personal needs according to moral, spiritual, cultural, educational preferences, achievement of the highest quality of working life.

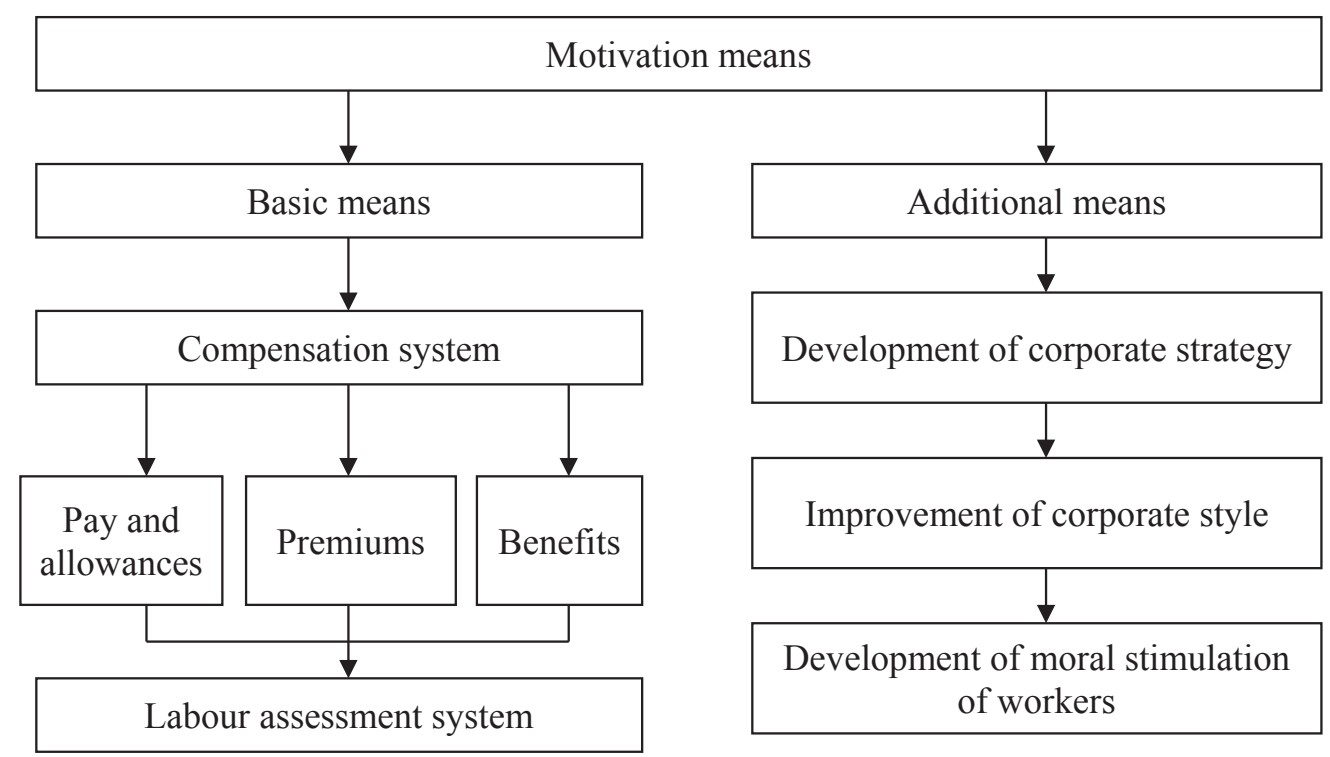

Fig. 3. Model of the system of improvement of personnel motivation means

Compiled by the author based on: Zhyvko, 2010; Iliash, Kaperyz, 2011 
It is advisable to create a motivational system at an enterprise in such a way that each employee is interested in delegating more weight to his authority and directing each one to a positive result.

The effectiveness of the system of motivation should be evaluated in three parameters: personnel loyalty; productivity of personnel activities; company's attractiveness in the labour market.

We determine prospects of further research by the following directions. It is necessary to develop performance indicators for employees based on the set strategic objectives of the enterprise, and not simply to make the implementation of certain indicators dependent on wage payment. In this way, each employee will work to achieve the goals set by the enterprise and will be personally interested in their achievement through the system of motivation.

\section{References:}

Day G.S., Wensley R. (1988). Assessing advantage: a framework for diagnosing a competitive superiority, Marketing Strategy, p. 127-158.

Dykan N. V. (2008). Menedzhment: navch. posibnyk [Fundamentals of management: the Navy messenger]. Kyiv: Znannya.

Hutorova O. O. (2009). Osnovy menedzhmentu: navch. Posibnyk [Fundamentals of management: the Navy messenger]. Kharkiv: KhNAU (in Ukraine).

Verkhohlyadova N. I., Yadranskyy D. M., Ivannikova N. A. (2008). Ekonomika pidpryyemstva [Economy of enterprises]. Kyiv: «Vydavnychyy dim «Profesional».

Korytko S. (2012). Formuvannya systemy motyvatsiyi pratsi na pidpryyemstvi [Formation of the system of motivation of labor at the enterprise]. Retrieved from: http://kerivnyk.info/2012/05/korytko.html

Iziumtseva N.V., Myronchuk H.V. (2012). Orhanizatsiia systemy motyvatsii bankivskoho personalu v umovakh postkryzovoho rozvytku ekonomiky [Organization of the system of motivation of banking personnel in the conditions of post-crisis economic development]. Menedzhment personalu: Visnyk Universytetu bankivskoi spravy Natsionalnoho banku Ukrainy. Management of personnel: Herald of the University of Banking of the National Bank of Ukraine, №1, pp. 279-283.

Iliash O.I., Kaperyz M.V. (2011). Posylennia motyvatsii pratsi v systemi upravlinnia trudovym potentsialom pidpryiemstva [Strengthening the motivation of labor in the system of management of the labor potential of the enterprise]. Economy, planning and management of the branch: Scientific Bulletin of the NLTI of Ukraine, Vol. 21.2, pp. 167-171.

Kindermann H. (2002). Formuvannia mekhanizmu motyvatsii pratsivnykiv aparatu upravlinnia pidpryiemstva [Formation of the mechanism of motivation of employees of the enterprise management machinery]. Management and entrepreneurship in Ukraine: stages of formation and development problems: Bulletin of the National University "Lviv Polytechnic". Lviv. Vol. 457, pp. 122-128.

Kozak K.B. (2011). Vplyv motyvatsii na efektyvnist vykorystannia ta rozvytku trudovoho potentsialu personalu [Influence of motivation on efficiency of use and development of labor potential of personnel]. Economy of food industry, No. 1, pp. 69-74.

Kushneryk O.V. (2012), Zarubizhni modeli motyvatsii pratsi personalu na pidpryiemstvi [Foreign models of personnel motivation at the enterprise]. Bulletin of the University of Ukraine, No. 15, pp. 98-103.

Larka MI, Zorina M.O. (2016). Suchasna model systemy stymuliuvannia najmanoho personalu na vyrobnychomu pidpryiemstvi [Modern model of the system of incentives for hired personnel at a production enterprise]. Technical progress and production efficiency. No 14/7. Retrieved from: // www.kpi.kharkov.ua.

Muzychenko-Kozlovskyj A.V., KolodijchukA.V.(2011) Osnovni elementy mekhanizmu motyvuvannia pratsivnykiv [The main elements of the mechanism of motivation of workers]. Scientific Bulletin of NLTU of Ukraine. Vol. 21.6, pp. 361-367.

Nikitin Y.O., Rukas-Pasichnyuk V.G .(2016). Suchasni modeli ta mekhanizmy motyvatsii personalu ukrainskykh pidpryiemstv [Modern models and mechanisms of motivation of personnel of Ukrainian enterprises]. Topical problems of the economy. Vol. 4 (154), pp. 238-353.

Potemkin O.V. (2011). Systemnyj pidkhid u motyvatsii pratsivnykiv bankivskoi sfery [Systemic approach to the motivation of banking industry workers]. Economic forum. No. 1. Retrieved from: archive.nbuv.gov.ua

Semenov AG, Sharko A.I. (2009). Aktualizatsiia teorij motyvatsii ta stymuliuvannia pratsi personalu na promyslovykh pidpryiemstvakh [Actualization of theories of motivation and stimulation of labor at the industrial enterprises]. State and regions. No.7, pp. 179-185.

Semikina M.V. (2011). Nova paradyhma motyvatsii pratsi v systemi rozvytku sotsialno-trudovykh vidnosyn [New paradigm of labor motivation in the system of development of social-labor relations]. Economy and management. No. 3, pp. 11-117. 
Temchenko O., Lisnichenko O. (2010). Vrakhuvannia motyvatsijnoi skladovoi pry rozrobtsi mekhanizmu materialnoho stymuliuvannia robitnykiv na promyslovykh pidpryiemstvakh [Taking into account the motivational component when developing the mechanism of material stimulation of workers at industrial enterprises]. Economic analysis. Vol. 7, pp. 350-353.

Watson P., Maslow D., Chileshe N. Deploying Total Quality Management in Russia (2004) European Quality Vol. 11, No. 2, pp. 58-71.

Watson P., Chileshe N., Maslow D. A (2004). New Model For Obtaining Sustainable Competitive Advantage. Construction Industry Development 2nd Postgraduate Conference - Cape Town, South Africa, 10-12 October, pp. 129-141.

Zhyvko Z.B. (2010). Mekhanizm motyvuvannia ta modeli motyvatsii personalu na vuhledobuvnykh pidpryiemstvakh [Mechanism of motivation and models of personnel motivation at coal-mining enterprises]. Management and marketing. Science and Economics, no. 1, pp. 86-91. 